\begin{abstract}
Global ocean circulation models usually lack an adaquate consideration of high-latitude processes due to a limited model domain or insufficient resolution. Without the processes in key areas of the global thermohaline circulation, the characteristics and flow of deep and bottom waters cannot be modelled realistically. In this study a high-resolution ( $\sim 20 \mathrm{~km})$ ocean model focused on the Weddell Sea sector of the Southern Ocean is combined with a low-resolution $\left(2^{\circ} \times 2^{\circ}\right)$ global ocean model applying the state estimation technique. Temperature, salinity, and velocity data on two Weddell Sea sections from the regional model are used as constraints for the large-scale model in addition to satellite altimetry and sea surface temperatures. The differences between the model with additional constraints and without document that the Weddell Sea circulation exerts significant influence on the course of the Antarctic Circumpolar Current with consequences for Southern Ocean water mass characteristics and the spreading of deep and bottom waters in the South Atlantic. Furthermore, a warming trend in the period 1993 to 2001 was found in the Weddell Sea and adjacent basins in agreement with float measurements in the upper Southern Ocean. Teleconnections to the North Atlantic are suggested but need further studies to demonstrate their statistical significance.
\end{abstract}

Key words. State estimation Adjoint method Weddell Sea Global ocean 


\title{
On the influence of adequate Weddell Sea characteristics in a large-scale global ocean circulation model
}

\author{
H. H. Hellmer, M. P. Schodlok, M. Wenzel and J. G. Schröter \\ Alfred Wegener Institute for Polar and Marine Research, Bussestr. 24, 27570 Bremerhaven, Germany
}

Received: date / Revised version: date

\section{Introduction}

The Weddell Sea is the Southern Ocean's strongest source of water masses contributing to the deep branch of the global thermohaline circulation based on observations and model results (Carmack 1977; Orsi et al. 1999; Hellmer and Beckmann 2001). The South Scotia Ridge (SSR) separating the northwestern Weddell Sea from the Scotia Sea (Fig. ??) represents a natural topographic barrier for these deep waters to directly escape from the Weddell Sea. A select few gaps with maximum sill depths of around $3000 \mathrm{~m}$ (Orkney Passage) allow for the passage of ventilated waters (Weddell Sea Deep Water - WSDW), which continue either westward to Drake Passage along the northern slope of the ridge as a deep boundary jet (Nowlin and Zenk 1988; Gordon et al. 2001) or northward into the eastern Scotia Sea (Naveira Garabato et al. 2002a; Schodlok et al. 2002). The fate of WSDW, being the source of the classical Antarctic Bottom Water (AABW, Wüst 1935), on its progression is still uncertain. It either ascends into the Lower Circumpolar Deep Water (LCDW) carried by the Antarctic Circumpolar Current (ACC) (Locarnini et al. 1993) or continues northward as AABW in to the Argentine Basin (Naveira Garabato et al. 2002a). The former process, driven by the interaction of the ACC with rough topography, certainly modifies the density structure of the ACC and, therefore, its dynamical balance ? (Olbers and Wübber 1991).

Flow and water mass characteristics of the WSDW crossing the ridge are subject to seasonal and interannual variability (Robertson et al. 2002; Schröder et al. 2002) caused by local winds, sea ice forcing acting in the inner Weddell Sea, and/or changes within and at the eastern extension of the Weddell gyre (Schröder and Fahrbach 1999). Water mass property anomalies have been observed in the eastern Scotia Sea (Meredith et al. 2001) and southern Drake Passage (Rubython et al. 2001), the western entrance to the Scotia Sea. Here, changes in deep water characteristics have a more direct impact on the ACC which experiences an increase in volume transport and in density as it passes the Scotia Sea. In particular, LCDW which contributes $\sim 20 \%$ to the total ACC volume transport (Sloyan and Rintoul 2001) is cooled and freshened. However, it is still subject to discussion whether cross-isopycnal mixing of LCDW and WSDW is responsible for these changes or whether this occurs by isopycnal flow from the northwestern Weddell toward the ACC (Naveira Garabato et al. 2002a). A possible source for the latter would be the Weddell-Scotia Confluence, a well mixed band stretching eastward from the Antarctic Peninsula along the crest of the SSR (Whitworth et al. 1994). The study indicates that environmental conditions in Bransfield Strait and on the adjacent continental shelf have a strong influence on ACC dynamics.

Only in recent years the interaction between the ACC and waters leaving the Weddell Sea became subject to intensive field work, e.g., as part of the international DOVETAIL (Deep Ocean VEntilation Through Antarctic Intermediate Layers) program (Muench and Hellmer 2002). However, numerical studies still have to be designed, as even regional models are rather coarse, to resolve the topographic details of the SSR with passages only a few kilometers wide. To study the influence of Weddell Sea waters on the dynamics of the ACC and their escape from the Southern Ocean, we apply a global circulation model which has been optimized for state estimation over periods of 10 years and more (Wenzel et al. 2001; Wenzel and Schröter 2002). This model is constrained to observations of sea surface elevation and temperature between 1993 and 2001. Although its performance is, in general, acceptable, the ACC is too wide and a strong warming trend is observed near Antarctica. To further study this area and to investigate its influence on larger scales, we prescribe averaged monthly means from two sections (top to bottom) of a high-resolution $(20 \mathrm{~km})$ model for the Weddell Sea as additional "soft" constraints for a global model using the adjoint method (Wenzel et al. 2001). The model results of the Weddell Sea are not only in agreement with observations (e.g. Naveira Garabato et al. 2002b) in terms of water mass characteristics and gyre transport but provide information about passage transports and their interannual variability (Schodlok et al. 2002). We therefore expect that the general circulation of the global model improves mostly in the vicinity of the additional data. 


\section{Model description}

We use the Hamburg Large Scale Geostrophic model (LSG, Maier-Reimer and Mikolajewicz 1991) to perform two assimilation experiments that differ in additional constraints for the Weddell Sea. This model was originally designed for climate studies with time scales of thousands of years (e.g. MaierReimer et al. 1993). In combination with its adjoint, however, it has also been used successfully for ocean state estimation (e.g. Wenzel et al. 2001; Wenzel and Schröter 2002; Staneva et al. 2002). The model version used in this paper has $2^{\circ} \times 2^{\circ}$ horizontal resolution, 23 vertical layers (varying from $20 \mathrm{~m}$ thickness for the top layer to $750 \mathrm{~m}$ for the deepest ones), and the implicit formulation in time allowing for a time step of ten days. The overall bottom topography of the model is derived from the Scripps $1^{\circ}$-topography (Gates and Nelson 1975) but modified/improved in the South Atlantic to better fit to the topography of the high-resolution Weddell Sea model (Schodlok et al. 2002). Compared to the original coding two improvements to the model were implemented. The model's evolution of the sea surface height now includes the effects due to steric expansion, and the description of the convective adjustment allows for a $50 \%$ entrainment in addition to the exchange of unstable layers. Although global models with resolutions less than $1^{\circ} \times 1^{\circ}$ are operated routinely at climate modeling centers with superior computer facilities, this coarse version of a global model allows for fast sensitivity studies to various constraints on prevalent computers.

\subsection{Data}

The data sets utilized in the standard assimilation experiment (SDR) described here are:

- monthly sea surface temperatures for the period 1993 2001 (Reynolds et al. 2002)

- ten day gridded fields of sea surface height anomalies as measured by the TOPEX/Poseidon altimetric mission for the period 1993-2001

- the SHOM98.2 mean sea surface height (CLS) referenced to the EIGEN-GRACE01S geoid (GfZ)

- temporal mean transports of mass, fresh water, and heat as obtained by different authors and summarized by, e.g. Bryden and Imawaki (2001) and Wijffels (2001)

- temperature and salinity of the Levitus climatology (WOA94), but with large error bars thus serving only as background information

Since the SDR solution shows essential deficiencies in the Weddell Sea circulation (see below) an additional assimilation experiment (WEDEX) is performed in which a 9-year (1985-1993) average of monthly mean temperatures, salinities, and horizontal velocities is constrained on two sections running across the inner Weddell Sea from Kapp Norvegia to Joinville Island, and along the SSR crest from Joinville to the South Sandwich Islands (Fig. ??, section I and II, respectively). The corresponding data is taken from the highresolution model for the Weddell Sea BRIOS-1.1 (Schodlok et al. 2002). Although its simulation period (1985-1993) does not coincide with our period of assimilation (1993-2001), the use of the results is justified because of the seasonal cycle being the dominant signal.

\subsection{Model technique}

We look for a global ocean state that is as close to the observations as possible. To combine the model and the data we use the adjoint method which is a variational optimization method. It is based on the definition of a costfunction $\mathbf{J}$ that describes the misfit between the data and corresponding model counterparts in an Eulerian sense. J implicitly depends on a set of control parameters that have to be adjusted to achieve minimum cost. The model's trajectory is totally determined in space and time by its initial conditions and the surface forcing fields (wind stress, air temperature, and freshwater flux). Therefore, it appears to be natural to use these as control parameters but with one exception: only the initial temperature, salinity, and sea surface height are subject to optimization. The initial velocities are not directly modified by the procedure. Instead, we allow them to adjust to the changed initial density structure during the first year of integration. The comparison between the data and the model, i.e. the evaluation of the costfunction, thus starts with year two of the simulation.

To reduce the number of control parameters of the optimization, we use a Hilbert Empirical Orthogonal Function (HEOF) decomposition for the surface forcing fields. The HEOFs are a special group of the complex Empirical Orthogonal Functions (CEOF), described in detail by von Storch and Zwiers (1999, Chap.16). The major advantage of such a decomposition for representing the forcing is that only the amplitudes of variability patterns that occur naturally are allowed to be adjusted. No unrealistic bulls-eye like fluxes are possible to correct for local model errors keeping the optimized forcing fields as realistic as possible. Ths obvious disadvantage is that it may introduce spurious teleconnections. Here we focus on the influence of the Weddell Sea data on the global solution. Therefore, both experiments, SDR and WEDEX, start from the same first guess for the control parameters. The model's initial state is derived by a model spinup with 1000 years of perpetual 1950-forcing fields from the NCEP re-analysis followed by an integration forward to the actual start time of the experiments, again using the NCEP , re-analysis as forcing. The first guess fields of the temporal mean and the trend of the forcing within the period of our interest as well as their HEOF amplitudes are taken as obtained in the basic decomposition of the corresponding forcing fields (see above).

\section{Model results}

The model results described in this section resemble

- the individual results (temperature and salinity) of the two simulations (SDR and WEDEX) and

- the differences between the simulations (WEDEX - SDR). 


\subsection{Mean temperature \& salinity distribution}

For the inner Weddell Sea, the additional constraints improved the vertical distribution of water mass characteristics. A colder water column is accompanied by a shift of the warm core to the east (Fig. ??a vs. Fig. ??b) as part of the eastern limb of the Weddell gyre inflow (Schröder and Fahrbach 1999). Its placement at mid-depth $(\sim 600 \mathrm{~m})$ and a temperature decrease towards the bottom, both seen in the high-resolution results (Fig. ??c), is missing in the global model due to the lack of dense water masses produced on the continental shelf of the southern Weddell Sea. The vertical salinity structure changed from a continous increase with depth to a more homogenous distribution with strong gradients near the top and both continental slopes (not shown). The latter indicates the existance of the relatively fresh coastal current traversing the Weddell Sea from east to west. Salinities, however, decreased to even lower values presumably due to an insufficient representation of the sea-ice formation process on the continental shelf.

Temperature improvements along the SSR vary regionally (Fig. ??a vs. Fig. ??b). Although the water column west of the South Orkney Islands is cooler, the water mass characteristics are far from being realistic (close to observations). The cold core $\left(-1.6^{\circ} \mathrm{C}\right)$ close to the Antarctic Peninsula, originating from the southwestern continental shelf in the highresolution simulation (Fig. ??c), is replaced with a relatively warm $\left(2.0^{\circ} \mathrm{C}\right)$ core indicating a still too southerly ACC course (Fig. ??b). The latter could possibly be less if continental shelf processes become part of the model, strengthening the gyre circulation and providing the cold water masses from the western Weddell Sea continental shelf. To the east of the South Orkney Islands, a gradual west to east temperature decrease in the SDR experiment (Fig. ??a) changes to core-like features (Fig. ??b) related to a meandering of the Scotia or Weddell Front (Orsi et al. 1995), both fringing the WeddellScotia Confluence to the north and south, respectively. While the temperatures of these cores match observations rather well, temperatures below $2000 \mathrm{~m}$, i.e., the flow in to the Scotia Sea is too warm with roughly $0.6^{\circ} \mathrm{C}$. Along the SSR, the vertical salinity structure also improved with lower surface salinities but again with values too low for most of the water column (not shown) for reasons already discussed for the inner Weddell Sea.

\subsection{Horizontal velocities and transports}

The improved temperature and salinity distribution is directly linked to a dramatic change in the Weddell Sea circulation as the distribution of horizontal velocities at 2000-m depth shows. The southern flow in the western Weddell Sea (Fig. ??a), due to an incursion of the ACC, reversed reflecting the cyclonic nature of the Weddell gyre (Fig. ??b). Central velocities of $\mathrm{O}\left(1 \mathrm{cms}^{-1}\right)$ agree with observations (Fahrbach et al. 1994), but velocities at the continental boundaries are too small. Since the processes on the continental shelf are not considered in this model together with a strong numerical diffusivity, the density contrast across the slope front and, therefore, the baroclinic component of the gyre circulation is reduced. The ACC incursion occurs above $2500 \mathrm{~m}$ depth be- cause flow below is blocked by the SSR. In WEDEX (Fig. ??b) this blocking facilitates deep waters formed in the Weddell Sea to escape north through Orkney Passage $\left(40^{\circ} \mathrm{W}\right)$. In the northern Scotia Sea, the upper $(<2000 \mathrm{~m})$ ACC splits into two branches. The western branch can be associated with the Malvinas Current, the eastern with the Polar Front, thus causing a more differentiated circulation in the South Atlantic, i.e., an intensification of the Brazil and South Atlantic Currents. In contrast, the deep Argentine Basin shows a reduced gyre circulation.

In Drake Passage a slow-down of the ACC starts at $1100 \mathrm{~m}$ depth, extending all the way to the bottom. Since transport through Drake Passage is weakly constrained to a time-mean of $135 \mathrm{~Sv}$, less deep flow is compensated by enhanced surface flow near the coast of South America. A phenomenon, beyond the scope of this paper but noteworthy, is the slow-down of the Labrador Sea gyre. Such interhemispheric connection between the formation sites for North Atlantic Deep Water (NADW) and AABW has already been reported by Brix and Gerdes (2003).

The barotropic transport streamfunction predominantly changes in the South Atlantic where the Weddell gyre now forms the double-cell structure (Fig. ??) mentioned earlier by, e.g., Beckmann et al. (1999). Its strength increased to $>30 \mathrm{~Sv}$, similar to the value resulting from the coupled ice-ocean model BRIOS-2 (Timmermann et al. 2002). Further consequences of the additional constraints in the Weddell Sea are a narrowing of the ACC with higher transports at its northern boundary and an 50\%-increase in strength of the South Atlantic subtropical gyre. In the Amundsen and Bellingshausen Seas (ABS) the ACC broadens extending onto the continental shelf after a major shift to the south at $\sim 150^{\circ} \mathrm{W}$. This position corresponds to the eastern limb of the main Ross gyre (Assmann and Timmermann 2005) which is missing in the global model possibly due to the lack of constraints and/or representation of relevant processes in the Ross Sea. Further changes for the rest of the world ocean are considered as spurious correlations.

\subsection{Heat \& salt content}

The differences (WEDEX minus SDR) of the temporal means of water column heat content for the period 1993 to 2001 show a cooler Weddell Sea from top-to-bottom with a minimum in the 500 to $2250-\mathrm{m}$ layer. This cooling is related to the retreat of the ACC and the westward shift in gyre circulation mentioned in Section ??. Although the results in general improved, the comparison with observations across the Weddell Sea (Fahrbach et al. 1994) reveals that WEDEX temperatures below $1000 \mathrm{~m}$ are still too homogenous and too warm due to missing bottom water newly formed at the cointinental shelf break. In contrast to the Weddell Sea, the lowestlayer (2250 $\mathrm{m}$ to bottom) in Ross, Amundsen, and Bellingshausen Seas became warmer (Fig. ??). The temperatures in the whole water column of the Argentine Basin increase causing a slightly enhanced meridional heat transport across $30^{\circ} \mathrm{S}$ which amounts to $0.19 \mathrm{PW}$. As mentioned earlier, warming of the lower layers in the Ross Sea and adjacent basins might be less with additional constraints in the Ross Sea area. 
The differences of the temporal means of water column salt content for the period 1993 to 2001 show a dipole structure across the Antarctic Peninsula with surface salinization in the Weddell Sea (freshening in ABS) and a switch to freshening (salinization) for all layers below (Fig. ??). Noteworthy is the saltier South Atlantic over the whole depth reducing the north-south density gradient with possible consequences for the meridional overturning in the North Atlantic.

\subsection{Analyzed trends for 1993-2001}

In the following the linear trends (changes from 1993 to 2001) of the WEDEX simulation are discussed. The additional constraints in the Weddell Sea provide a more consistent picture resulting in trends smaller for WEDEX than for SDR. It is worth mentioning that trends at the surface are mainly imposed by the observations of sea surface temperature (SST) and height $(\mathrm{SSH})$ while trends at greater depth are subject to the model physics. As a consequence of changed circulation patterns, and temperature and salinity distributions, specific ocean layers experience different developments/trends in their heat and salt content. The surface layer $(<500 \mathrm{~m})$ shows no immediate trend in the vicinity of the Weddell Sea and a very patchy structure of warming and cooling in the South Atlantic (Fig. ?? - upper). The eastern Ross Sea $\left(210^{\circ} \mathrm{E}\right)$ shows a strong cooling whilst in the western Ross Sea no trend exists in the upper ocean. The cooling trend in the Ross Sea intensifies between $500 \mathrm{~m}$ and $2250 \mathrm{~m}$ (Fig. ?? - middle). For the same depth range, the ACC in the South Atlantic sector as well as the eastern Weddell Sea show a warming trend, thus influencing water masses entering the inner Weddell Sea. This trend changes sign at depths $>2250 \mathrm{~m}$, i.e., a cooling of the eastern Weddell Sea, Prydz Bay area $\left(\sim 70^{\circ} \mathrm{E}\right)$, and the ACC in the South Atlantic, and a warming of the southeast Pacific (Fig. ?? - lower). The most striking feature is the strong warming of the deep central Scotia Sea despite the close proximity of the constraint to the south. This trend might be related to the eastward advection of the southeast Pacific warming with the ACC and the northward advection of cold water masses of Weddell Sea origin restricted to the eastern Scotia Sea.

The heat content of the global ocean increases almost linearly for the 9-year period. Compared to the SDR solution it is, however, strongly reduced when Weddell Sea data is included in the estimation (not shown). Especially in the bottom layer the warming trend becomes negligible while the change in the upper ocean $(<512.5 \mathrm{~m})$ for the period 1993 2001 closely resembles the trend of the sea surface elevation as measured by altimetry (Wenzel and Schröter 2002).

For the trend in salt content, major changes occur in the surface layer of Amundsen, Bellingshausen, and Ross Seas (Fig. ?? - upper). There is almost no upper ocean trend in the Weddell Sea and little freshening in the northern South Atlantic. A reversed trend is seen in the layer between 500 to 2250-m depth with a freshening of the Ross Sea and the Southeast Pacific (Fig. ?? - middle). As for the heat, the salinity signal migrates through Drake Passage in to the Scotia Sea and further downstream reflecting the change of ACC properties. Consequently, the central South Atlantic freshens but its boundary currents become more saline due to the intensifica- tion of the Brazil Current. No uniform trend can be seen in the lowest layer of the South Atlantic (Fig. ?? - lower), possibly reflecting the different routes deep water of Weddell Sea origin is forced by topography to take on its way north. The freshening in the deep southwestern Indian Ocean might result from the eastward spreading of fresher Weddell Sea deep waters.

\section{Discussion and conclusions}

Improved constraints in the southern model domain related to a better representation of the Weddell Sea hydrography naturally causes a more realistic situation in the adjacent South Atlantic. The major improvements are related to a redirection of the ACC in the southern Scotia Sea due to the westward displacement and strengthening of the cyclonic Weddell gyre. Consequences for the ACC transport, however, cannot be studied by this model because the time-mean transport through Drake Passage is weakly constrained to $135 \mathrm{~Sv}$.

The westward shift of the gyre allows for the transfer of colder (but still warmer than observed) and relatively fresh water masses from the interior Weddell Sea in to the adjacent basins. The opposed distribution in the temporal mean salt content of the whole water column (Fig. ??) to the west of the Antarctic Peninsula indicates that flow in to the southeast Pacific via the slope front/coastal current related to the Antarctic Slope Front (Whitworth et al. 1998) occurs only sporadically. The structure might be related to the Antarctic Dipole manifested at the surface in the sea ice variability in the western Amundsen Sea and central Weddell gyre (Yuan and Martinson 2001). The changes in the layers below are caused by a shift of the area of enhanced deep convection from the southeast Pacific to the Weddell Sea (not shown). Here, convection is driven by more realistic surface fluxes causing a saltier (than in SDR) upper ocean (Fig. ??). Bottom currents tunneling the ACC as they pass Scotia Sea, Georgia and southern Argentine Basins carry Weddell Sea characteristics in to the circumpolar current and further north. Nevertheless, secondary centers of activity in the trends of heat and salt can be identified in Amundsen, Bellingshausen, and eastern Ross Seas.

The cooling and freshening in the eastern Ross Sea is caused by a more meridional flow of the ACC at the position of the eastern limb of the Ross Sea gyre. In the Southeast Pacific south of $60^{\circ} \mathrm{S}$ temperature and salinity maximum, corresponding to Upper and Lower Circumpolar Deep Water, are located within the depth range 500-1000 m (http://www.awibremerhaven.de/GEO/eWOCE). Therefore, a slight change in flow path can result in differences between both simulations. Since bottom topography is identical, atmospheric forcing only slightly adjusted, and the Ross Sea gyre did not develop, the modification of the ACC flow in this area has to be related to a change in the density structure triggered by the, in general, warmer and saltier Amundsen and Bellingshausen Seas. The only source for such changes in water mass characteristics, however, is the ACC itself, indicating that Weddell Sea characteristics exert a significant influence on the circumpolar course of the current.

A tight connection between the Argentine Basin and the Weddell Sea coincides with earlier observations that the west- 
ern South Atlantic responds within roughly a decade to disturbances in the Weddell Sea (e.g. Coles et al. 1996) thus serving as a conduit between high and low latitudes. The response at the formation sites of NADW might be an artifact due to model deficiencies (see model description) but seems plausible considering the spreading of AABW in the Atlantic Ocean (Emery and Meincke 1986) and the interplay between the NADW and AABW cells studied with a global coupled ice-ocean model (Brix and Gerdes 2003).

This study shows that the processes in the Weddell Sea significantly influence the hydrography of the Southern Ocean and South Atlantic. A similar result has to be expected for the South Pacific if the characteristics of the Ross Sea are adaquately considered. The latter might also cause significant changes in the Indian Ocean as Ross Sea disturbances travel westward with the coastal current (Beckmann and Timmermann 2001). The connection between Weddell and Amundsen/Bellingshausen Seas via the coastal current, as proposed in earlier studies (e.g. Hellmer 2004), cannot be supported by this model certainly due to its insufficient resolution at the northern margin of the Antarctic Peninsula.

The maximum trend (WEDEX) in water column heat content of $8 \mathrm{~W} \mathrm{~m}^{-2}$ for the $512-2250 \mathrm{~m}$ depth range in the eastern Weddell Sea (Fig. ?? - middle) corresponds to a warming of $0.035^{\circ} \mathrm{C} \mathrm{a}^{-1}$. This is similar to the warming estimated for the upper Southern Ocean (700-1100 m) by Gille (2002). However, the reduced trend in WEDEX compared to SDR indicates that the warming in the Southern Ocean predicted by global climate simulations (e.g. Manabe et al. 1991) could be less if southern high-latitude processes are considered in more detail.

As a next step, data from the Ross Sea should be used as additional constraints in the South Pacific while the ACC transport through Drake Passage should be allowed to develop unopposed. The latter would allow to study all aspects of the interaction between Weddell gyre and ACC, and both steps possibly have serious consequences for the modeled Southern Ocean and deep world ocean.

Acknowledgments Thanks to S. Esselborn for providing the TOPEX/Poseidon altimeter data, to U. Mikolajewicz and two anonymous reviewers for careful reading and a constructive evaluation, and to the editors of Ocean Dynamics for a courageous handling of the manuscript.

\section{References}

Assmann KM, Timmermann R (2005) Variability of dense water formation in the Ross Sea. Ocean Dyn in press

Beckmann A, Hellmer HH, Timmermann R (1999) A numerical model of the Weddell Sea: Large-scale circulation and water mass distribution. J. Geophys Res 104: 23374-23391

Beckmann A, Timmermann R (2001) Circumpolar influences on the Weddell Sea: indication of an Antarctic Circumpolar Coastal Wave. J. Clim 14: 3785-3792

Brix H, Gerdes R (2003) NADW and AABW: Their interaction and influence on the variability of the global ocean circulation. $\mathrm{J}$. Geophys Res 108: DOI 10.1029/2002JC001335

Bryden HL, Imawaki S (2001) Ocean heat transport. In: Siedler G, Church J, Gould J (eds) Ocean Circulation and Climate, Academic Press, Intern Geophys Ser 77: 455-474
Carmack EC (1977) Water characteristics of the Southern Ocean south of the Polar Front. In: Angel M (ed) A Voyage of Discovery - George Deacon $70^{t h}$ Anniversary Volume, Pergamon Press, pp $15-41$

CLS: SHOM98.2 mean sea surface http://www.cls.fr/html/oceano/projets/mss/cls_shom_e

Coles VJ, McCartney MS, Olson DB, Smethie Jr WM (1996) Changes in Antarctic Bottom Water properties in the western South Atlantic in the late 1980s. J. Geophys Res 101: 8957-8970

Emery WJ, Meincke J (1986) Global water masses: summary and review. Oceanol Acta 9: 383-391

Fahrbach E, Rohardt G, Schröder M, Strass V (1994) Transport and structure of the Weddell Gyre. Ann Geophys 12: 840-855

Gates, WL, Nelson AB (1975) A new (revised) tabulation of the Scripps topography on a 1 degree global grid. Part II: Ocean depths. Tech Rep R-1277-1-ARPA, The Rand Corporation, Santa Monica, CA

GfZ: EIGEN-GRACE01S geoid. http://op.gfz-potsdam.de/grace/index_GRACE.html

Gille ST (2002) Warming of the Southern Ocean since the 1950s. Science 295: 1275-1277

Gordon AL, Visbeck M, Huber B (2001) Export of Weddell Sea Deep and Bottom Water. J. Geophys Res 106: 9005-9018

Hellmer HH, Beckmann A (2001) The Southern Ocean: A ventilation contributor with multiple sources. Geophys Res Lett 28: 2927-2930

Hellmer HH (2004) Impact of Antarctic ice shelf basal melting on sea ice and deep ocean properties. Geophys Res Lett 31: L10307 DOI10.1029/2004GL19506

Locarnini RA, Whitworth III T, Nowlin Jr WD (1993) The importance of the Scotia Sea on the outflow of Weddell Sea Deep Water. J. Mar Res 51: 135-153

Maier-Reimer E, Mikolajewicz U (1991) The Hamburg Large Scale Geostrophic Ocean General Circulation Model (Cycle 1). Tech Rep No. 2, Deutsches Klimarechenzentrum, Hamburg

Maier-Reimer E, Mikolajewicz U, Hasselmann K (1993) Mean circulation of the Hamburg LSG OGCM and its sensitivity to the thermohaline surface forcing. J. Phys Oceanogr 23: 731-757

Manabe S, Stouffer RJ, Spelman MJ, Bryan K (1991) Transient response of a coupled ocean-atmosphere model to gradual changes of atmospheeric $\mathrm{CO}_{2}$. Part 1: Annual mean response. J. Clim 4: 785-818

Meredith MP, Naveira Garabato AC, Stevens DP, Heywood KJ, Sanders RJ (2001) Deep and bottom waters in the eastern Scotia Sea: rapid changes in properties and circulation. J. Phys Oceanogr 31: 2157-2168

Muench RD, Hellmer HH (2002) The international DOVETAIL program. Deep-Sea Res II 49: 4711-4714

Naveira Garabato AC, Heywood KJ, Stevens DP (2002a) Modification and pathways of Southern Ocean deep waters in the Scotia Sea. Deep-Sea Res 49: 681-705

Naveira Garabato AC, McDonagh EL, Stevens DP, Heywood KJ, Sanders RJ (2002b) On the export of Antarctic Bottom Water from the Weddell Sea. Deep-Sea Res II 49: 4715-4742

Nowlin Jr WD, Zenk W (1988) Westward bottom currents along the margin of the South Shetland island arc. Deep-Sea Res 35: 269301

Olbers D, Wübber C (1991) The role of wind and buoyancy forcing of the Antarctic Circumpolar Current. In: Latif M (ed) Strategies for Future Climate Research, MPI Hamburg, pp 161-192

Orsi AH, Whitworth III T, Nowlin Jr WD (1995) On the meridional extent and fronts of the Antarctic Circumpolar Current. Deep-Sea Res 42: 641-673

Orsi AH, Johnson GC, Bullister JL (1999) Circulation, mixing, and production of Antarctic Bottom Water. Prog Oceanogr 43: 55109

Reynolds RW, Rayner NA, Smith TM, Stokes DC, Wang W (2002) An improved in situ and satellite SST analysis for climate. J. Clim 15: 1609-1625 
Robertson R, Visbeck M, Gordon AL (2002) Long-term potential temperature trends in the deep waters of the Weddell Sea. DeepSea Res II 49: 4791-4806

Rubython KE, Heywood KJ, Vassie JM (2001) Interannual variability of bottom temperatures in Drake Passage. J. Geophys Res 106: 2779-2793

Schodlok MP, Hellmer HH, Beckmann A (2002) On the transport, variability, and origin of dense water masses crossing the South Scotia Ridge. Deep-Sea Res 49: 4807-4825

Schröder M, Fahrbach E (1999) On the structure and the transport in the eastern Weddell Gyre. Deep-Sea Res 46: 501-527

Schröder M, Hellmer HH, Absy JM (2002) On the near-bottom variability in the northwestern Weddell Sea. Deep-Sea Res 49: 47674790

Sloyan BM, Rintoul SR (2001) The Southern Ocean limb of the global deep overturning circulation. J. Phys Oceanogr 31: 143173

Staneva J, Wenzel M, Schroeter J (2002) Oceanic state during 19931999 determined by 4D Var data assimilation. WOCE International Newsletter 42: 11-13

Storch H von, Zwiers FW (1999) Statistical Analysis in Climate Reseach. Cambridge University Press

Timmermann R, Beckmann A, Hellmer HH (2002) Simulations of ice-ocean dynamics in the Weddell Sea 1. Model configuration and validation. J. Geophys Res 107: DOI10.1029/2000JC000741

Wenzel M, Schröter J, Olbers D (2001) The annual cycle of the global ocean circulation as determined by 4D VAR data assimilation. Prog Oceanogr 48: 73-119

Wenzel M, J. Schröter J (2002) Assimilation of TOPEX/POSEIDON data in a global ocean model: differences in 1995-1996. Phys Chem Earth 27: 1433-1437

Whitworth III T, Nowlin Jr WD, Locarnini RA, Smith SG (1994) Weddell Sea shelf water in the Bransfield Strait and WeddellScotia Confluence. Deep-Sea Res 41: 629-641

Whitworth III T, Orsi AH, Kim SJ, Nowlin Jr WD, Locarnini RA (1998) Water masses and mixing near the Antarctic Slope Front. In: Jacobs SS, Weiss R (eds) Ocean, ice, and atmosphere: interactions at the Antarctic continental margin. Antarc Res Ser 75: $1-27$

Wijffels SE (2001) Ocean transport of fresh water. In: Siedler G, Church J, Gould J (eds) Ocean Circulation and Climate. Academic Press, Intern Geophys Ser 77: 475-488

Wüst G (1935) Schichtung und Zirkulation des atlantischen Ozeans. Das Bodenwasser und die Stratosphäre. Wiss. Ergeb. dtsch. atlant. Exped. Meteor 1925-27 6: 1-288

Yuan X, Martinson DG (2001) The Antarctic Dipole and its predictability. Geophys Res Lett 28: 3609-3612 


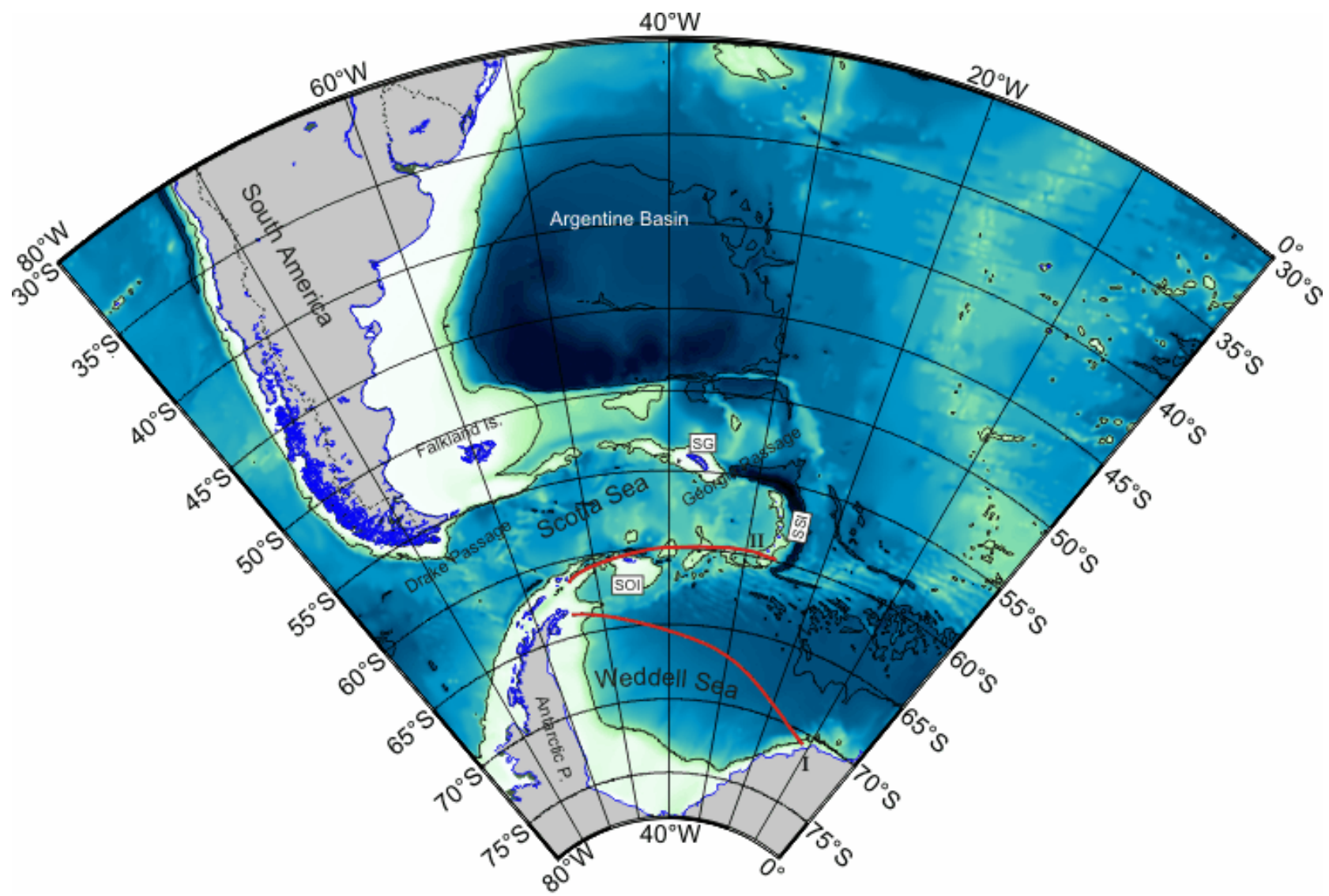

Fig. 1. Geographic map of the Southern Ocean between $80 \mathrm{deg} \mathrm{W}$ and Greenwich Meridian including the two sections (red lines) across the Weddell Sea (I) and along the South Scotia Ridge (II). From these sections high-resolution $(20 \mathrm{~km})$, timeseries of temperature, salinity, and velocity were extracted to provide additional constraints for the global LSG model. Plotted are the 2000 and 5000-m isobaths. SOI: South Orkney Islands, SSI: South Sandwich Islands, SG: South Georgia. 


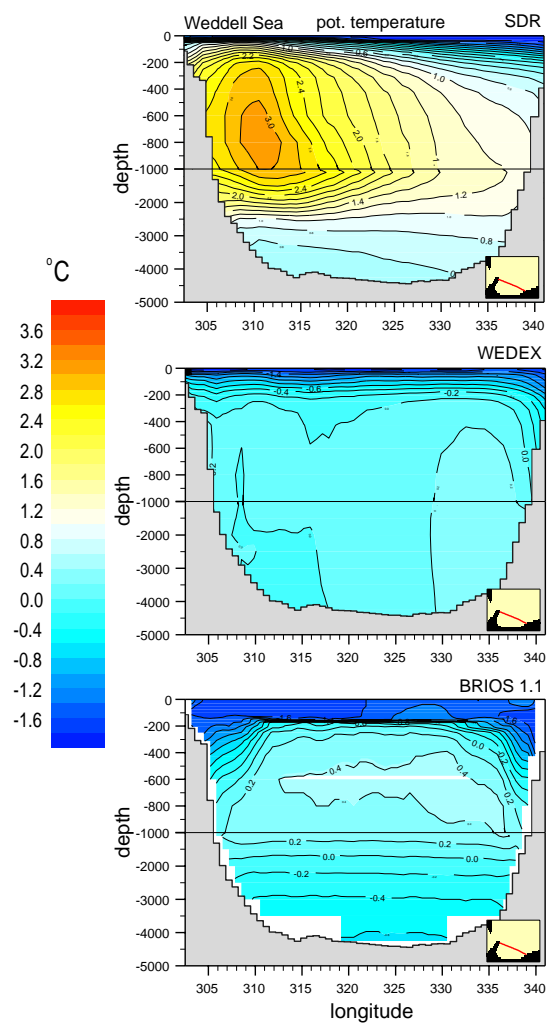

Fig. 2. 9-year (1993-2001) average of potential temperature for the Weddell Sea section (I in Fig. ?? and insert) from the experiment (a) without and (b) with constraints in the Weddell Sea, compared with (c) the 9-year average (1985-1993) of the high-resolution numerical model (BRIOS-1.1) which provided the additional constraints. Upper $1000 \mathrm{~m}$ are streched for better visibility. 


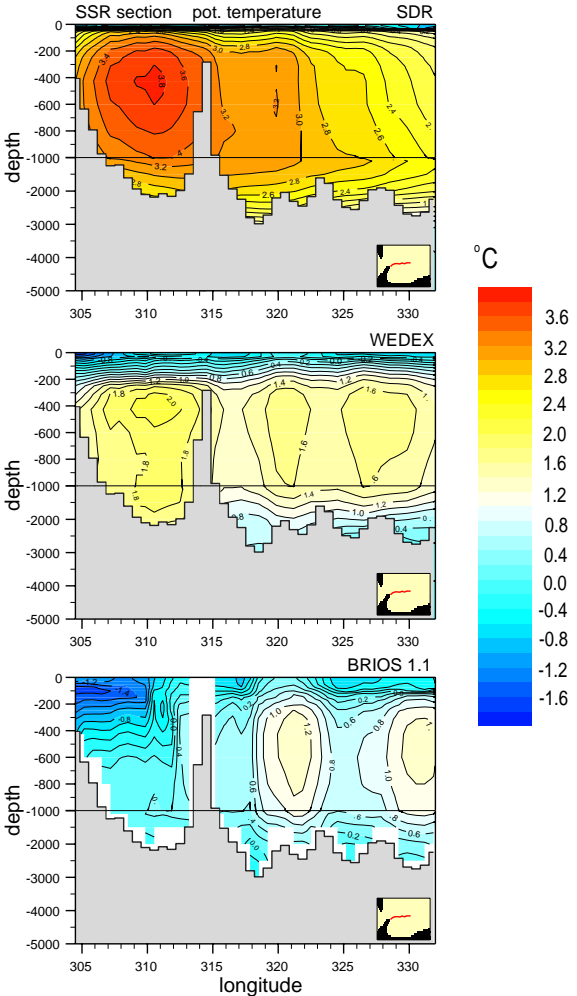

Fig. 3. 9-year (1993-2001) average of potential temperature for the South Scotia Ridge section (II in Fig. ?? and insert) from the experiment (a) without and (b) with constraints in the Weddell Sea, compared with (c) the 9-year average (1985-1993) of the high-resolution numerical model (BRIOS-1.1) which provided the additional constraints. Upper $1000 \mathrm{~m}$ are streched for better visibility. 

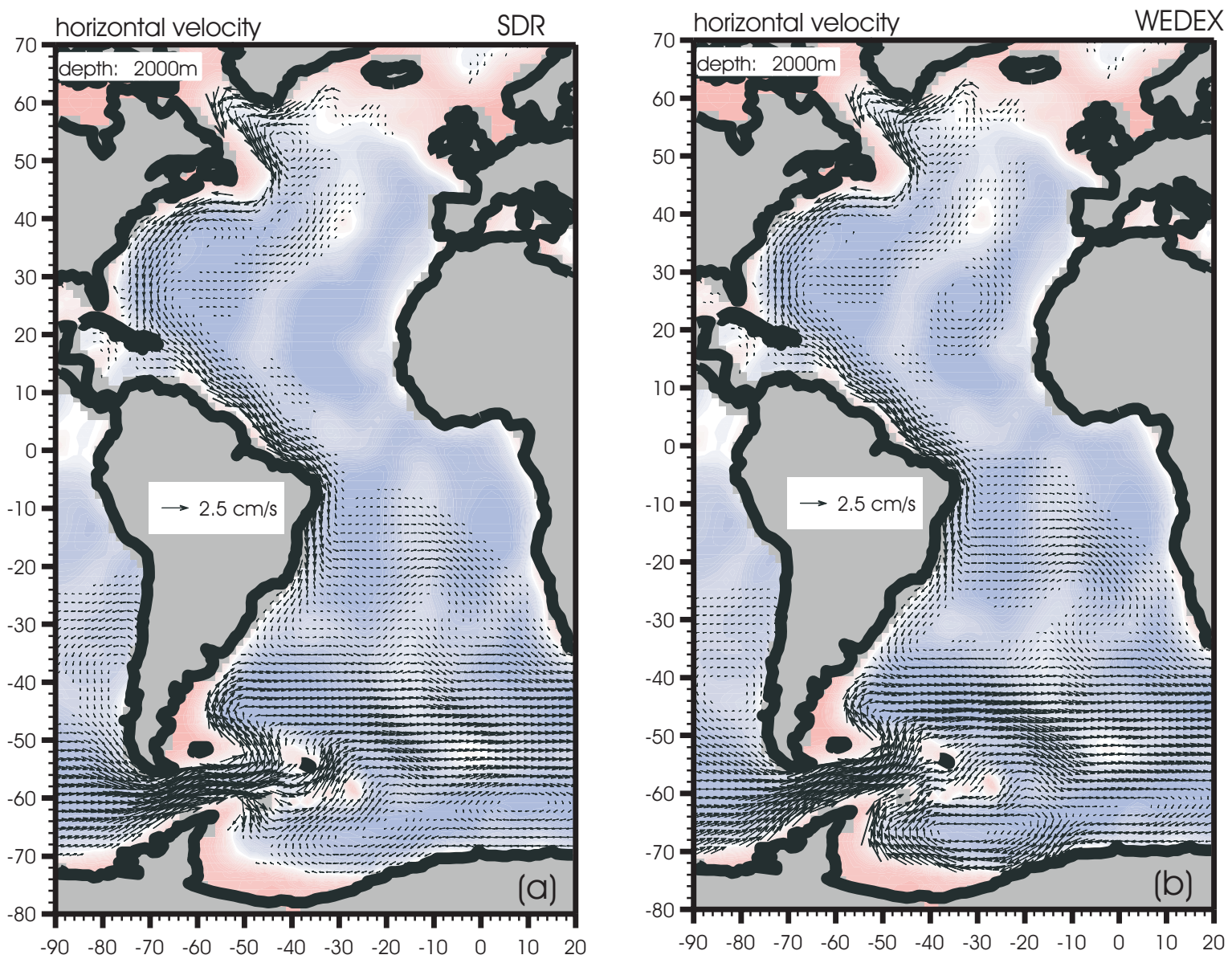

Fig. 4. 9-year (1993-2001) average of velocities at 2000-m depth for the Atlantic Ocean from the experiment (a) without and (b) with constraints in the Weddell Sea. Background color represents bottom topography with transition from blue to pink at $2500 \mathrm{~m}$ depth. 


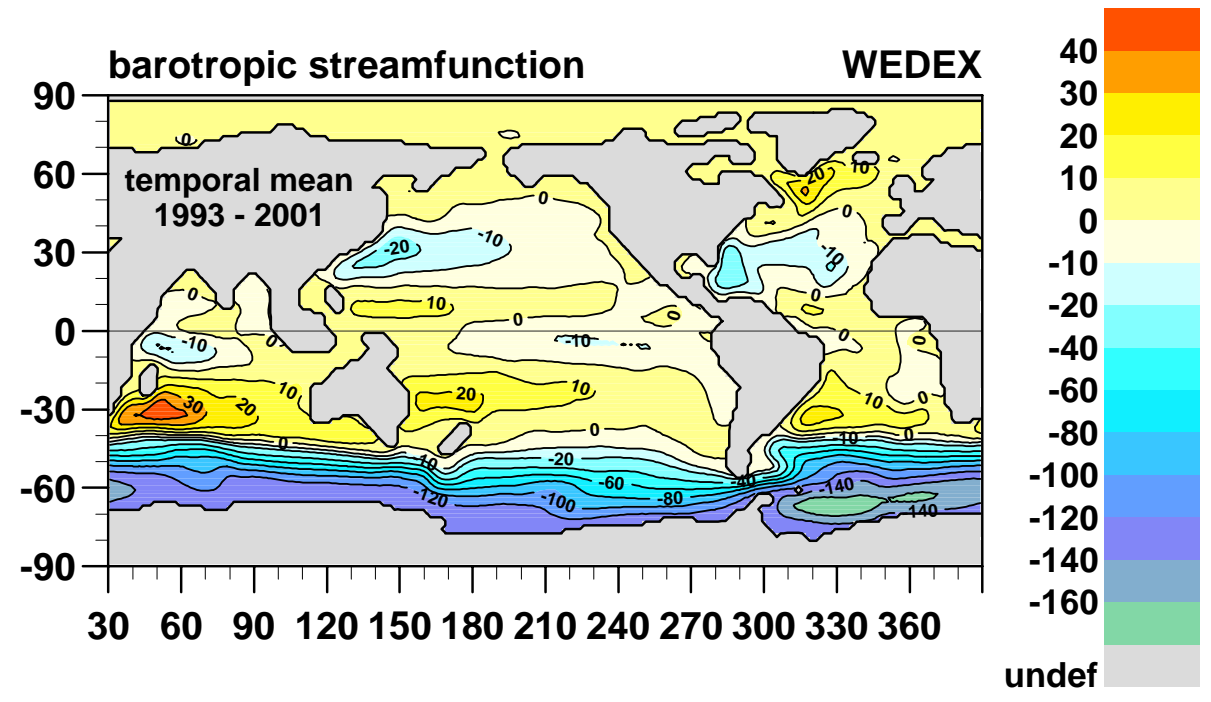

Fig. 5. Global distribution of barotropic transport streamfunction as temporal mean of the period 1993-2001 from the experiment with constraints in the Weddell Sea. Contour interval is $10 \mathrm{~Sv}$ with positive/negative values representing anticyclonic/cyclonic circulation. 


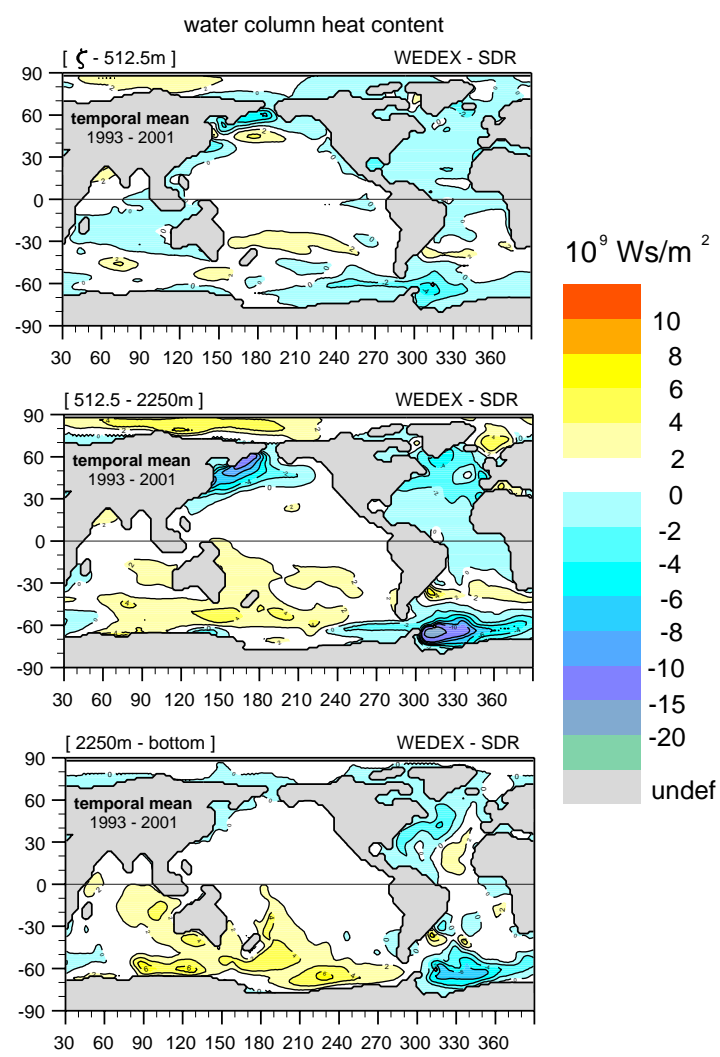

Fig. 6. Difference of the 9-year (1993-2001) average of water column heat content between the experiments with and without constraints in the Weddell Sea for three distinct depth ranges surface to $512.5 \mathrm{~m}$ (upper), $512.5 \mathrm{~m}$ to $2250 \mathrm{~m}$ (middle), and $2250 \mathrm{~m}$ to the bottom (lower). Contour interval is $2 \mathrm{Ws} \mathrm{m}^{-2}$ with positive/negative values representing a warmer/cooler water column. 


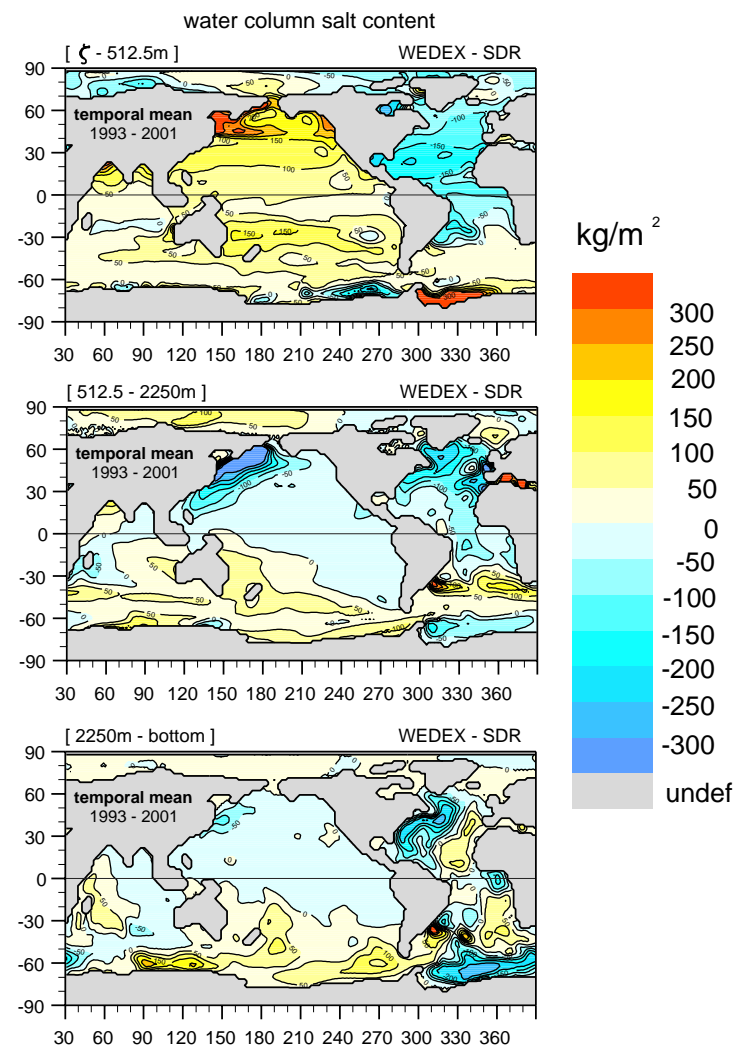

Fig. 7. Difference of the 9-year (1993-2001) average of water column salt content between the experiments with and without constraints in the Weddell Sea for three distinct depth ranges surface to $512.5 \mathrm{~m}$ (upper), $512.5 \mathrm{~m}$ to $2250 \mathrm{~m}$ (middle), and $2250 \mathrm{~m}$ to the bottom (lower). Contour interval is $50 \mathrm{~kg} \mathrm{~m}^{-2}$ with positive/negative values representing a saltier/fresher water column. 


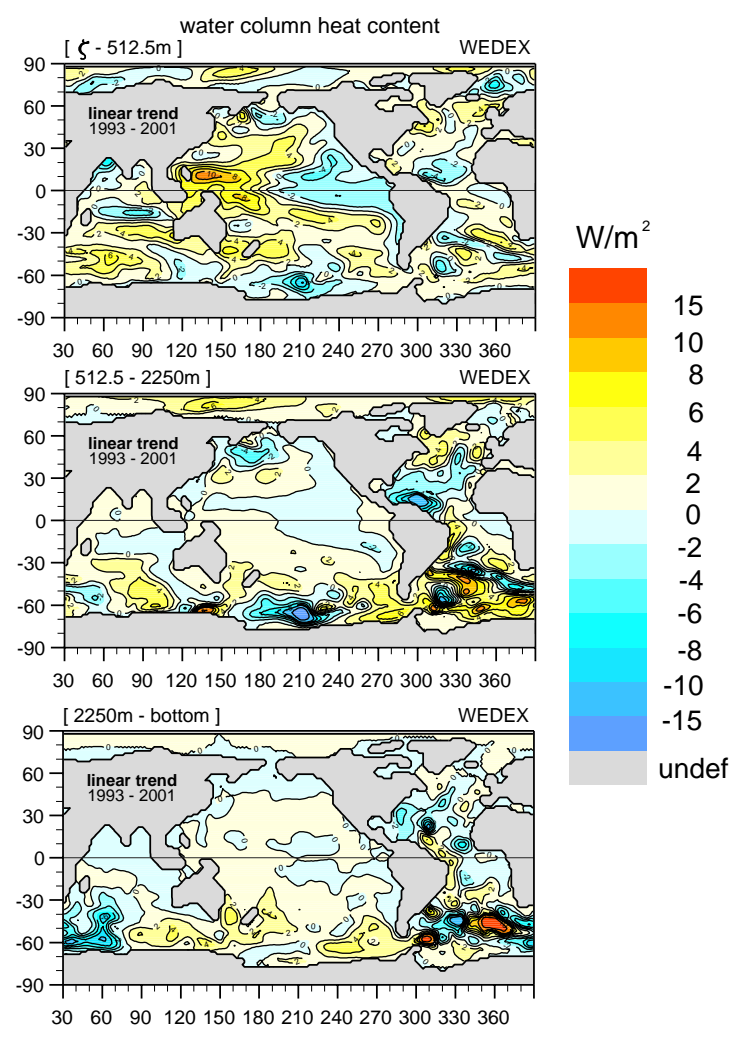

Fig. 8. Linear trend of water column heat content for the period 1993-2001 of the experiment with constraints in the Weddell Sea separated for three distinct depth ranges surface to $512.5 \mathrm{~m}$ (upper), $512.5 \mathrm{~m}$ to $2250 \mathrm{~m}$ (middle), and $2250 \mathrm{~m}$ to the bottom (lower). Contour interval is $2 \mathrm{~W} \mathrm{~m}^{-2}$ with positive/negative values representing a warming/cooling of the water column. 


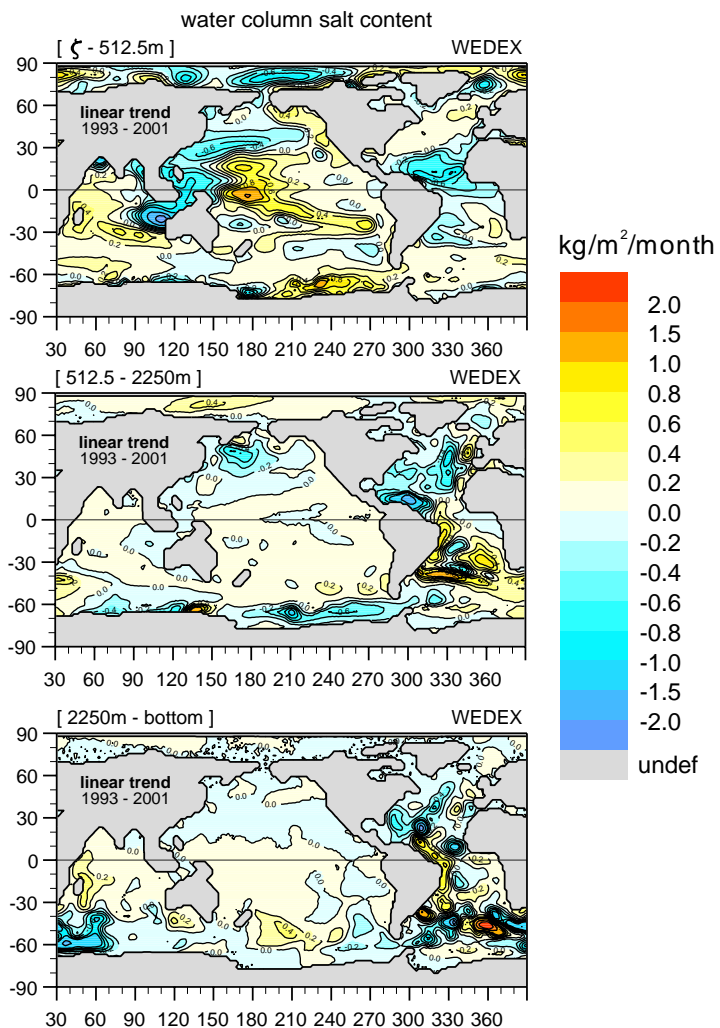

Fig. 9. Linear trend of water column salt content for the period 1993-2001 of the experiment with constraints in the Weddell Sea separated for three distinct depth ranges surface to $512.5 \mathrm{~m}$ (upper), $512.5 \mathrm{~m}$ to $2250 \mathrm{~m}$ (middle), and $2250 \mathrm{~m}$ to the bottom (lower). Contour interval is $0.2 \mathrm{~kg} \mathrm{~m}^{-2}$ month $^{-1}$ with positive/negative values representing a salinization/freshening of the water column. 